\title{
THE RULE OF THE ADMIRALS
}

Law, Custom, and Naval Government in Newfoundland, $1699-1832$

The Rule of the Admirals examines governance in Newfoundland from the rule of the fishing admirals in 1699 to the establishment of representative government in 1832. It offers the first in-depth account of the rise and fall of the system of naval government that dominated the island for more than a century.

In this provocative look at legal culture in eighteenth- and nineteenthcentury Newfoundland, Jerry Bannister explores three topics in detail: naval government in St John's, surrogate courts in the outports, and patterns in the administration of law. He challenges the conventional view that early Newfoundland was a lawless frontier isolated from the rest of the Atlantic world, and argues that an effective system of naval government emerged to meet the needs of those in power.

The Rule of the Admirals sheds light on one of the most misunderstood chapters in Canadian and British colonial history. Drawing on extensive archival research as well as a broad range of secondary sources, Bannister provides a groundbreaking reinterpretation of a critical period in Newfoundland's colonial development.

(The Osgoode Society for Canadian Legal History)

JERRY BANNISTER is an assistant professor in the Department of History at Dalhousie University. 


\title{
PATRONS OF THE SOCIETY
}

\author{
Aird \& Berlis LLP \\ Blake, Cassels \& Graydon LLP \\ Davies, Ward Phillips \& Vineberg LLP \\ McCarthy Tétrault LLP \\ Osler, Hoskin \& Harcourt LLP \\ Torkin Manes Cohen \& Arbus LLP \\ Torys LLP \\ WeirFoulds LLP
}

The Osgoode Society is supported by a grant from

The Law Foundation of Ontario.

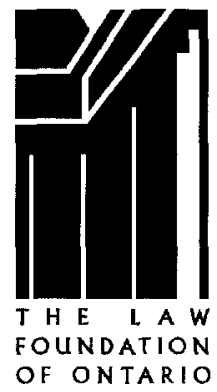

The Society also thanks The Law Society of Upper Canada for its continuing support. 


\section{THE RULE OF \\ THE ADMIRALS}

\section{Law, Custom, \\ and Naval Government in \\ Newfoundland, 1699-1832}

JERRY BANNISTER

Published for The Osgoode Society for Canadian Legal History by University of Toronto Press Toronto Buffalo London 


\section{www.utppublishing.com}

(C) Osgoode Society for Canadian Legal History 2003

All rights reserved. No part of this publication may be reproduced, stored in a retrieval system, or transmitted in any form or by any means, electronic, mechanical, photocopying, recording, or otherwise, without the prior written permission of the publisher.

Printed in Canada

ISBN 0-8020-8843-0 (cloth)

ISBN 0-8020-8613-6 (paper)

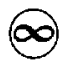

Printed on acid-free paper

National Library of Canada Cataloguing in Publication

Bannister, Jerry, 1968-

The rule of the admirals : law, custom, and naval government in

Newfoundland, 1699-1832 / Jerry Bannister.

Includes bibliographical references and index.

ISBN 0-8020-8843-0 (bound). ISBN 0-8020-8613-6 (pbk.)

1. Justice, Administration of - Newfoundland and Labrador -

History. 2. Newfoundland and Labrador - Politics and government To 1763. 3. Newfoundland and Labrador - Politics and government1763-1855. I. Osgoode Society for Canadian Legal History. II. Title.

KEN1365.B35 $2003 \quad 347.718 \quad$ C2003-903629-4

University of Toronto Press acknowledges the financial assistance to its publishing program of the Canada Council for the Arts and the Ontario Arts Council.

University of Toronto Press acknowledges the financial support for its publishing activities of the Government of Canada through the Book Publishing Industry Development Program (BPIDP).

This book has been published with the help of a grant from the Canadian Federation for the Humanities and Social Sciences, through the Aid to Scholarly Publications Programme, using funds provided by the Social Sciences and Humanities Research Council of Canada. 
For my parents, Marina and Gerald Bannister, and for Patti, with love. 
This page intentionally left blank 